Ingeborg Jandl

ingeborg.jandl@univie.ac.at

University of Vienna

Faculty of Philological and Cultural Studies

Department of Slavonic Studies https://doi.org/10.18485/knjiz.2021.11.11.5

UDC: 821.163.42.09-31 Дракулић С.

821.163.4(497.6).09-31 Башић А.

821.163.4(497.6).09-31 Хасанбеговић Д. 821.163.41(497.6).09-31 Басташић Л.

821:305-055.2

Original scientific article

\title{
The Artist and Her Muse: From Female Bodies towards Female Identities (Drakulić, Bašić, Hasanbegović, Bastašić) ${ }^{1}$
}

The paper approaches artistic self-concepts from the perspective of twenty-first-century female writers. Against the background of ancient and modern constellations of the artist and the muse, one main question will concern feminist strategies of coping with this ideal union that has been shaped within a patriarchal tradition of art production for centuries. Slavenka Drakulić, Adisa Bašić, Dijala Hasanbegović, and Lana Bastašić use a variety of subversive strategies to challenge and transform the given constellation. Analysing the difficulties an emancipated modern muse faces when attempting to be recognised as an independent artist is only one possible first step to open this discussion. More active measures proposed in the selected literary examples are to reverse traditional gender roles in love relationships and to discredit male profiteers throughout the literary scene. The usefulness of such an approach shall also be discussed, considering that the ideal relationship between a muse and an artist as one of inspiration and creation must not be destroyed.

Keywords: female identities, artistic self-concepts, concepts of the muse, subversive writing

\section{The Artist and the Muse}

Inspired by the classical topos of the artist and his muse as the ideal symbiosis of creation and inspiration, in this article I will answer the question of how this union develops in case of female artists. If creative power is represented by a female subject, will she draw inspiration from a male partner and, more generally, what are the implications of such a change ${ }^{2}$ To shed light on this question, I will discuss four contemporary examples from postYugoslav literature: Slavenka Drakulić's historical novel Dora i Minotaur (2015; Dora and the Minotaur) deconstructs the classical concept of the male artist and his female muse by highlighting how seduction and psychological violence intertwine. In the fictional story " $\mathrm{A}$ ti zaključaj” (2017; Would You Lock the Door?), Adisa Bašić reverses the artistic relationship into that of a female artist and a male muse, who, however, does not fulfil his part as a source of inspiration. Toxic masculine surroundings of female artists are present in Dijala Hasanbegović's poem “Moj prvi single” (2017; My First Single), in which the lyrical subject 
does not even think of relying on a muse. Lana Bastašić's female character in the novel Uhvati zeca (2018; Catch the Rabbit, 2021) narrates several unfruitful relationships with men, while she finds love and inspiration in the imaginary connection with her childhood sweetheart, whose traces disappeared at the beginning of the Yugoslav war.

The classical relationship between the artist and his muse represents a patriarchal order, in which the creative act is executed by a male protagonist, while the female part is limited to accompanying this process. It is necessary to mention that this constellation originally did not degrade female identity. Since antiquity, poets like Homer have started important epic poems with an invocation of the muse, asking her for inspiration and for the gift of speech. The word 'muse' initially signified the creative product as well as creative power, which is the relevant meaning in the context of this article. Already in ancient times, this power of creation was personified as the 'goddess of creation', whom the poets would address (cf. Bie 1894-1897: 3238f). The early concept of the muse, thus, referred to an inner value of inspiration rather than the sexualised female body that is accentuated in modernity.

The ancient concept stayed productive in European literature and developed according to different contexts. Ivan Gundulić's epic poem Osman, written in the first half of the seventeenth century, is only one example from South-Slavic baroque literature where the poet revives this tradition and invokes the muses as a positive and divine power:

$\begin{array}{ll}\text { O djevice čiste i blage } & \text { (Oh maidens pure and gentle } \\ \text { ke vrh gore slavne i svete } & \text { who upon the mountain glorious and saint } \\ \text { slatkom vlasti pjesni drage } & \text { sweet rule over dear song } \\ \text { svijem pjevôcim naričete, } & \text { to all poets lend, } \\ \text { narecite sad i meni [...]. } & \text { lend it now to me as well [...].) })^{3}\end{array}$

(Gundulić 1990: 24)

In the given constellation, the maidens stay physically distant. Gundulić implicitly refers to the ancient myth, according to which the muses are situated on Mount Helicon. In addition, he regards them as “a form of remembering” (Tutter 2017: 2), which Adele Tutter emphasises in her conceptualisation of the ancient muses as Mnemosyne's daughters. Furthermore, Gundulić's poem follows the ancient tradition: his lyrical subject asks the muses for inspiration and to lend him the right words. One, thus, may read the (male) poet as a (passive) medium of creation through which the (female) muses' speech will be materialised. 
The topos of the muse changes in modernity, where it becomes closely connected to erotic experience. ${ }^{4}$ The (male) artist is attracted by the sexualised female body and gains inspiration from the physical union with his muse or desperately dreams of possessing her. This leads to a conceptual overlapping between the muse and the femme fatale: the female allegory of inspiration is no longer seen simply as divine, pure, and wise but becomes ambiguous, demanding, and unpredictable. Such a trend can especially be observed within the European Künstlerroman (cf. Jandl 2016: 494), which replicates the traditional gender roles of a male creator and a female source of inspiration. Important South Slavic examples can be found in Antun Gustav Matoš’s story “Helena” (1909) (cf. Jandl 497-499) and in Miroslav Krleža’s novel Povratak Filipa Latinovicza (1932, The Return of Philip Latinovicz). ${ }^{5}$ Both texts show the fatal consequences of replacing the divine muse with an enticing woman: with their appearances, Helena and Bobočka attract the attention of their respective artists and provoke their desire. Nowhere in the texts, however, does one find a remark on their inspiring wisdom. The artists' imaginative powers are not bestowed by these incarnate muses but by the male gaze and, what is more, they are not directed towards the act of creation but lead to a fixation: the wish of possessing the women.

A similar problem provides the setting in Slavenka Drakulić's Dora, if we read this novel from Picasso's perspective. The painter's abusive relationships with women are the result of his artistic obsession: he encounters them in connection with his arts, that is to say, as muses who promise the gift of creation to him: “Ta fotografija odredila mi je život: kad se u nju zagledao Picasso, zaljubio se u indijansku princezu. U model, ne u mene.” (Drakulić 2015: 41) (This photograph determined my fate: when Picasso contemplated it, he fell in love with an Indian princess. With the model, not with me.) This imaginary relationship with a muse is demystified by everyday life, with the result that his metaphysical addressee loses the attributed power of inspiration and becomes an undesirable object. The parallel to texts from the beginning of the twentieth century results from the historical context of the novel, through which Drakulić revives the historical concept of the muse. She has, however, chosen a different focus. Drakulić does not problematize the male artist's conflict of solipsism that arises from his confusion of an attractive woman with an inaccessible muse but emphatically traces the consequences for his misread partner.

Attempts to question the gendered tradition of the artist and his muse are a logical consequence of feminist achievements in the later decades of the twentieth century. Drakulić demonstrates in her novel that the muse is a victim in this early-twentieth-century understanding. Unlike an ancient goddess, the selfish genius forces her into a passive and 
subordinate position. At the same time, Drakulić tries to redefine Dora Maar's identity by shedding light on her own artistic ambitions and career. In the following close readings, I will not focus on the female muse but on the female artist and on how contemporary feminist writers challenge and define this concept. Slavenka Drakulić, Adisa Bašić, Dijala Hasanbegović, and Lana Bastašić use historical, fictional, or autofictional contexts to reflect upon the position of the female artist, which is a topic that indirectly also concerns their personal situation. How do they define the female creator, and where does she draw her inspiration from?

\section{Male Artist, Female Muse: Stolen Identity in Slavenka Drakulić's Dora i Minotaur}

\section{(Dora and the Minotaur)}

In the novel Dora i Minotaur, Slavenka Drakulić deals with the relationship between Dora Maar and Picasso. Drakulić focuses on the destructive part of this love story, elaborating on how Dora loses her own artistic self-concept as a well-educated woman and talented photographer by becoming Picasso's lover. At a reading in the Literary House Graz, Drakulić mentioned that she was interested in the private relationship of couples consisting of two talented partners. She empathically adopts the position of skilled women who are unable to fully actualize their talent or desires because they subordinate their own dreams to their partners' well-being and career. This series of biographically inspired novels also contains one about Frida Kahlo (Frida, ili o boli, 2007; Frida's Bed, 2008) and one about Mileva Einstein (Mileva Einstein, teorija tuge, 2016; Mileva Einstein, a Theory of Melancholy). ${ }^{6}$ These examples confirm one of Aage Hansen-Löve’s conclusions concerning female poets of Russian modernity: the time was not yet ripe for male muses, and the dual female role of an artist and a muse could lead to identity conflicts (cf. Hansen-Löve 2019: 689).

With Dora Maar's fictional autobiography, Drakulić summarises the gendered identity challenge of artistically gifted women as follows: "[Z]nate li da su samo žene dovedene u situaciju da biraju između toga da budu žene ili umjetnice?” (Drakulić 2015: 199) ([A]re you aware of the fact that only women are urged to make a decision to be either a woman or an artist?) In several constellations, she illustrates the conflict between Dora's part as a muse and as an artist. The main character tries to be both, and at the beginning of her career she successfully reconciles her fame as a photographer with being a femme fatale. Drakulić also uses Dora's case to illustrate the dissolute culture in artistic circles at the turn of the last century: “Umišljale smo da smo umjetnice i muze [...]. Bile smo sebične i okrutne.” (Drakulić 2015: 58f.) (We assumed that we were artists and muses [...]. We were selfish and cruel.) For Dora, 
her identity as an artist takes priority when she is trying to make a name for herself; promiscuity, however, can only be beneficial in this context: "Uskoro sam postala Dora Maar. S promjenom imena promijenio se i moj identitet.” (Drakulić 2015: 40f.) (Soon I became Dora Maar. With the change of name my identity also changed.)

According to Drakulić's interpretation, Dora refuses to be a muse in the classical way, i.e. a source of inspiration or the subject of an artwork, and chooses active parts for herself in terms of sexuality as well as in terms of art: "Kamera mi je pružila osjećaj sigurnosti i užitka. Ili možda moći. Užitka u moći, zašto ne?” (Drakulić 2015: 38) (The camera gave me a feeling of security and pleasure. Or maybe of power. The jouissance of power, why not?) The text presents a negative and passive concept of the muse, who is represented as the masochistic (female) complement of a sadistic (male) artist. For Dora, resisting means, on the one hand, to imitate the despotic, selfish behaviour of the artist and, on the other, to avoid a deep emotional involvement in the toxic reality of the bohemian milieu. The camera enables her to do this, but Dora gives in on both levels when she meets Picasso:

Zato jer sam se od svijeta, pa i od svojih prijatelja, morala braniti svojim fotografijama, staklom leće - inače bih postala poput Jacqueline ili Nusch, žena-žrtva. A to sam postala tek onog trenutka kad sam zauvijek odložila kameru. Jer me Picasso na to natjerao. Jer sam mu to dopustila. (Drakulić 2015: 59f.)

(Hence with the help of my photographs, with the glass of the lens, I had to resist the world, and also my friends - otherwise I would have become like Jacqueline or Nusch, a typical female victim. And this is what I became right at that moment when I laid aside my camera. Because Picasso forced me to do so. Because I allowed him to force me to do so.)

With regard to two earlier novels, Dagmar Burkhart (2004: 352) has pointed out that Drakulić avoids repeating a feminist discourse of women as victims: in Božanska glad (1995; The Taste of Men, 1997), ${ }^{7}$ she subverts traditional power relations and chooses a female firstperson narrator who kills her lover out of love and symbolically consumes parts of his body (the skin of his fingertips), invoking a ritual religious subtext. This 'good deed' follows a series of literary and filmic models with masculine protagonists and a prevalent male gaze that Drakulić transforms into a sexist view of men: Tereza makes her decision to murder José when 
she realises her fading desire for him and admits that he has become an object for her (cf. Burkhart 2004: 350).

Has Drakulić changed her position? By lending her voice to Dora, she re-enacts the experience of a woman who is conquered and emotionally destroyed by Picasso, the 'Minotaur'. On the surface, this constellation recalls the narrative of the woman as a victim. Although the text empathises with the female protagonist, the statement is not as simple as that. In a subtle way, Drakulić blames Dora for her own fate. This becomes especially apparent when she introduces a Venetian mask maker, who recommends the cat mask to her. He explains that this type of mask was originally linked to cross-dressing roles in the theatre, in which men played the roles of amorous women: "Gatta vam savršeno pristaje jer vidim u vama seksualnost, ali i muškost. I oholost [...]. Vaša je maska najljepša upravo zato jer nije maska [...].” (Drakulić 2015: 198) (The cat fits you perfectly well, because I recognise in you lewdness, but also masculinity. And pride [...]. Your mask is the most beautiful one, because it is not a mask [...].) Like a mirror, this encounter confronts Dora with her failure: she has no authentic personality, only a mask that hides her pain and emphasises her need for love and attention.

Throughout the novel, male gazes resolve her unintentional 'choice' between being a woman or an artist in the worst possible way. Already Picasso, just like the mask maker, associated her with masculinity, which means that both men call into question her identity as a woman. Furthermore, both attribute lewdness to her and thus move her identity as an artist beyond reach, by framing Dora as a dependent lover. To make matters worse, Dora discovers that she is infertile: "Ruke su mi prazne. Nemam djeteta, nemam kameru, nemam ništa." (Drakulić 2015: 139) (My hands are empty. I have no child, I have no camera, I have nothing.) In the end, Dora herself believes in the role of a muse that is imposed on her: "Ipak sam ostala francesa.” (Drakulić 2015: 205) (I stayed a prostitute, after all.)

Drakulić illustrates how Dora's regress is initiated by Picasso's personality but also by his art and creative work. The novel indicates how art and art production control the relation between a subject (the creator) and an object (the model). According to Drakulić, Picasso knew Man Ray's photograph of Dora as an Indian princess already before their personal acquaintance (see the quote in the previous chapter). This is what she will stay for him: a piece of art, an object, a muse. What is more, he repeats this approach in his paintings and even seems to reinforce her passiveness and submission: “Žena se ne odupire, ali ne gleda u njega. Pasivna je.” (Drakulić 2015: 75) (The woman does not resist, but she does not look at him. She is passive.) This is how Drakulić's Dora translates the gestures from Picasso's painting Dora and 
the Minotaur (1936). The conquered muse is contrasted with Picasso's portrait of himself as a violent lover, who claims: “Ja sam tvoj gospodar. Pokorit ću te.” (Drakulić 2015: 76) (I am your master. I will subdue you.) In retrospect, Dora recognises the suggestive force of Picasso’s paintings. The artist unveils in advance, and maybe even causes, her upcoming mental decline: “Sudeći po tim mojim portretima pretvarala sam se u Ženu koja plače.” (Drakulić 2015: 117) (Judging from my portraits, I was transforming into The Weeping Woman.)

Drakulić does not discard a productive love relationship of two artistic partners as impossible, and - like a proposition - depicts a short period of shared happiness. While Picasso is painting Guernica (1937), Dora photographs him: "Malo smo govorili. Moje je oko pratilo njegovu ruku u savršenoj harmoniji, u usklađenom ritmu, u tišini, da ne ometamo koncentraciju jedno drugome.” (Drakulić 2015: 99) (We hardly talked. My eye followed his hand in perfect harmony, and we worked in a synchronised rhythm, in silence, so as not to disturb each other.) Dora and Picasso reach genuine equality in a setting where both are artistically productive in their own field of expertise. Within this short episode, Dora even seems to be in a position of power, as she depicts Picasso with her camera. This is also when, according to Drakulić's interpretation, it comes to rival claims: Dora desires to reach Picasso’s artistic level, while he wants to rank first.

Such a conflict is never made a subject of discussion in the novel but can be read between the lines. Even though he is interested in experimenting with techniques of the photogram that he learns from Dora, Picasso refuses to accept her photographing as a discipline of art and tries to prevent her from further developing this talent: “Ostavi se fotoaparata, Doro. Slikaj! Ovo nije umjetnost. Probaj nešto drugo.” (Drakulić 2015: 113) (Forget the camera, Dora. Paint! This is not art. Try something new.) Picasso's unfavourable opinion of photography may also be linked to his own ability of producing perfect realist paintings that he had already developed in adolescence. Still, his wish to control Dora's art, on which Drakulić focuses, seems to become apparent in other contexts as well, e.g. in the attempt to monopolise her as his apprentice: “Znaš da su renesansni majstori imali učenike koji su dovršavali slike [...]?” (Drakulić 2015: 99) (Did you know that Renaissance artists had apprentices who finished their paintings $[\ldots]$ ?)

Even more subtle, Drakulić uses Dora’s perspective to depict Picasso as vain, not only regarding arts but also his appearance: "On se znao odjenuti gotovo svečano, u bijelu košulju, čak je vezao i kravatu. Možda zbog fotografiranja?” (Drakulić 2015: 99) (He would perfectly attire himself in a white shirt, even wear a tie. Maybe in order to be photographed?) Her hidden criticism of men is mainly directed against narcissistic tendencies and a lack of empathy for 
women. Similarly, Drakulić subliminally criticises also other male friends of Dora's. One of them is her later therapist Jacques Lacan, who tries to cure her from depression after a stay in the psychiatric hospital Saint Anne but never recommends to her that she should revive her favourite occupation, photography. Through Dora's eyes, Drakulić reproaches him for a masculine worldview and states that he is too busy with his own self-discovery to understand the mental state of his patient. Especially Gustave Courbet's painting L'Origine du monde (1866) in his office seems to demonstrate this, as she states: "Da sam muškarac, gledajući Porijeklo svijeta pomislila bih: pokoriti, savladati, kontrolirati." (Drakulić 2015: 177) (Looking at The Origin of the World as a man, my thoughts would be: subdue, seize, control.)

\section{Picasso's Guernica as the Battle of Two Equal Artists}

Drakulić substantiates her interpretation of the relationship between Picasso and Dora with reflections upon visual materials. She deduces the following key constellations: Picasso's attraction to an imago (Man Ray's photograph of the Indian princess from 1936), mutual love (an early photograph of the couple in the sea), rape and submission (Dora and the Minotaur, 1936), equality, closeness, rivalry between two artists (Guernica, June 1937), and finally Picasso’s sadistic triumph over Dora’s pride (The Weeping Woman, 26 October 1937, followed by a whole series of similar paintings). Departing from these materials, the novel sheds light on Dora's emotional states and her response to the transgressive love triangle that her relationship with Picasso turns out to be: unbeknownst to Dora, he has never broken up the love affair with his younger muse Marie-Thérèse Walter, the mother of their one-year-old daughter (cf. Caws 2000: 81). According to Drakulić's polemic interpretation, The Weeping Woman does not represent Picasso's allegoric mourning over the Spanish Civil War, as this painting is often interpreted, but a psychograph of Dora's long-lasting inner pain. Drakulić underlines the painter's passive and nearly apolitical view of the war, for which Dora, who has understood her own arts as political from the very beginning (cf. Caws 2000: 9), keeps criticising her famous partner.

Even in Guernica, Picasso's epic painting of this war, interdisciplinary studies recognise personal undercurrents, which do not deal with historic circumstances but with private relationships. Ora Attia points to the artist's repeated self-portrait as a bull, Minotaur or warrior: "Picasso's preceding works portraying soldiers or Minotaurs reveal that, apparently, the warrior, too, represents the artist, in addition to the Civil War soldiers” (Attia 2011: 1566). Especially Picasso's sketches for Guernica shed light on drastic changes in the relationships 
between his protagonists. Raul Hartke states that this "group of works centred on Guernica [...] are made up of triangular sexual scenes from which one of the participants is excluded [...]" (Hartke 2000: 124). The main symbolic components of this preselected central scene of the later Guernica are the bull, the warrior, the horse, a woman with a light in her hand, and a little Pegasus.

Starting with 1 May 1937, one sequence shows a love scene between the bull and the horse, the little Pegasus is sitting on the bull's back, the bull is looking into the same direction as the horse. This draft consists of two parts; at the top of the drawing, the woman with the light is extending her arm and head through a window, the bull is trying to approach her, but this seems difficult as the whole scene is flooded with water, only the bull's torso is visible (Abb. 1 May 1937 II, see the drawing in: Attia 2011: 1576). Hartke refers to another drawing from the same day, in which "the horse has a neck in the shape of a phallus and an opening in its belly” (Hartke 2000: 127; see: ibid. 136). In a further drawing from the same day, the horse is having sexual intercourse with the warrior, who is lying on the ground with a lance in his hand; the woman is holding the light directly over this scene, she has wings and her hand is directly above the bull, who is standing close to the horse but looking in the opposite direction, so that there is no eye contact between any of the characters. The horse is pregnant with the little Pegasus, and everyone except the woman seems to be satisfied (Abb. 1 May 1937 VI, see: Attia 2011: 1576). In a subsequent drawing also from this day, "horse and warrior are now dead [the horse might only be hurt - I. J.] - the warrior's head is severed, and his lance broken [...]. The woman with the lamp is lighting up the scene directly and the bull appears to be fleeing [and is turning its head, so that it is looking directly at the light-bearer woman - I. J.]” (Hartke 2000: 127; see: ibid. 136).

Obviously, the love relationship between the horse and the bull is short-lived. Within this cycle, the horse is depicted as the more active partner: in the first example, the bull is following her gaze, while the drafts of erotic scenes with the warrior frame the horse as the dominant and even aggressive part. Who is symbolised by this horse? Attia recalls what Françoise Gilot mentioned in her autobiographical book Vivre avec Picasso (1964): Picasso "told Gilot [...] that the horse was her symbol, and the bull, his [...]" (Attia 2011: 1566). As the artist made acquaintance with Françoise Gilot only in 1943, she cannot be depicted in Guernica. In light of the contexts, it is plausible to read the horse as a symbol of Picasso's then lover, Dora. She unites the strong, multi-layered temperament expressed by the horse and shares the self-confidence and identity of being an artist with Gilot. In addition, Picasso will portray Dora's face fifteen years later with the traits of a haggard and skull-like horse. Aage 
Hansen-Löve argues that the horse as a symbol of a woman who represents the anima or muse of the male protagonist was a common topos in canonical realist novels in the nineteenth century (cf. Hansen-Löve 2019: 215-217), which is a plausible background that could have influenced Picasso. In Guernica he added a white flash coming out of the horse's mouth, directed at the bull's head: it is reminiscent of a photographic flash and, thus, identifies Dora as a photographer. ${ }^{8}$

Picasso painted Guernica at a moment of intimacy and in her presence, one could even say in cooperation with her as a photographer. The most multifaceted character in the drafts of Guernica is the horse, which changes from friendly to phallic, fertile, stubborn, and aggressive. The horse is fighting and struggling with all its strength until the warrior's death and, if necessary, until its own breakdown. All this is still present in the final painting, where the horse expresses power, strength, and a claim to dominance.

As mentioned above, Picasso appears in this painting twice, and I would like to emphasise that he painted himself in two different ways, as an artist (the bull) and as a man (the warrior lying on the ground with a broken sword). The Minotaur that he uses in other contexts as his own symbol represents the unity of both. Especially the separation of the two identities allows him to characterise the relationship between Dora and himself in great detail. The early draft of the horse and the bull with the little Pegasus shows Picasso's initially positive view of their artistic collaboration: he paints the emotional and mental union of two harmonious, loving partners, from which he himself draws inspiration; little Pegasus is on his back, as their creative child, or the result of his creative period. This drawing does not show an artist and a muse but two artists who inspire each other.

If Dora and the Minotaur shows the painter violating his entirely passive muse Dora, so only one year later, in the drafts of Guernica, excessive sexuality and creation are inversely proportionally attributed to Dora, the horse. The little Pegasus, symbolising creation, is in her womb. As the dying warrior illustrates, Dora, the artist, becomes dominant and threatens Picasso’s narcissistic masculine identity. The bull (artist) is not directly involved in the sexual act anymore and is standing aside. Picasso, thus, now interprets Dora as an abusive, violent, and superior artist, while he has become the muse, mainly serving as a source of inspiration for her. The final painting of Guernica shows how Dora is wounding his masculine pride and is threatening Picasso with her artistic self-confidence. The photographic flash marks him as her subject. Furthermore, photography seems to be reflected in the predominance of artificial light: while working on the painting, Picasso replaced the sun at the top centre with a lamp, and the light bearer is passing him a source of artificial light, too. 
It seems more difficult to determine the light bearer's identity: the women in Guernica resemble Marie-Thérèse Walter, as she is depicted in Picasso's other paintings: smoothly rounded traits, fine blond hair, and often a natural, friendly, peaceful, and slightly naïve radiance. Picasso paints Dora's face differently with rough edges, strong colours, sometimes also with male traits in one half of her fragmented face, and she always has a striking facial expression, be it arrogance, criticism, anger, or grief. ${ }^{9}$ In Guernica, the prototype of MarieThérèse’s face appears four times: as a light bearer, a fleeing woman, a burning woman and a woman mourning her dead child. Interestingly, in the process Picasso changed the light bearer's hair from blond to dark so that this woman also becomes linked to Dora. ${ }^{10} \mathrm{He}$ also changed further details that blend features of both women. A possible interpretation might be that during this period both were his muses and inspired him as parts of a conflictual triangle, confirming his virility and male privileges.

\section{A Female Artist and a Male Muse: Adisa Bašićcs story "A ti zaključaj” ("Would You Lock the Door?”)}

While Drakulić points towards the mental and creative destruction of talented women through their transition from a subject to an object and exposes their growing helplessness and suffering, Adisa Bašić presents a self-confident female artist and a subordinate male lover. Thereby, she reverses the subject-object relation that defines the suffering of Drakulić's Dora on two levels: love and artistic creation. The female protagonist Arnela leaves for Berlin to advance her artistic career. She takes this as an occasion to break up with her gentle lover Samir, who cooks for her and cares for her emotional well-being. For Arnela, the farewell is clear from the very beginning of the story, while Samir can only guess the definite decision at the end of their last date. Once more, Bašić's female character is in the position of power.

Let us now see how Bašić thematises seduction and creation in her story "A ti zaključaj". It is important to know that the author wrote a dissertation on joyful erotic love and humour in South Slavic poetry (defended in 2019). In line with this, she narrates a relationship in which both partners have joyful sex together. At the same time, Bašić's female artist seems to consume her muse similarly to Drakulić's Picasso, who draws inspiration from sexual relationships with women. However, in spite of Arnela's active part in this love affair, Bašić does not give up a rather patriarchal concept of love and pleasure. The narrator seems to reproduce a hierarchy rather in accordance with the male gaze than with feminist liberation and underlines the male character's pleasure - not Arnela's or that of both characters: “Ona ima 
bezbroj lica i seks s njom je za Samira svaki put otkrivenje.” (Bašić 2017: 104) (She had countless faces, and sex with her was always a discovery for Samir.) This is striking because here we have a text with a very clear feminist intention written by a feminist author. And yet, the quality of female sex is outlined by a man who enjoys it.

The same perspective is found regarding artistic inspiration. Bašić underlines Samir's lack of artistic performance and understanding. The following quote outlines the part of arts in this relationship between the artist Arnela and her muse Samir:

Samir je ponosan. Zna da na to nema pravo jer ničim ne doprinosi njenoj umjetnosti, ali kad mu priča o svom radu, krizama, dilemama, uspjesima on osjeti da je dio nečeg velikog i važnog. U isto vrijeme zna da tamo ne pripada i plaši se tog njenog svijeta, privlačnog, nestalog i nemilosrdnog. (Bašić 2017: 103)

(Samir is proud. He knows that he has no right to this, as he does not contribute to her art in any way, but when she talks to him about her work, her crises, dilemmas, successes, he feels that he is part of something great and important. At the same time, he knows that he does not belong to this world and fears it as something attractive but unsafe and pitiless.)

Bašić clearly attributes artistic creation as well as artistic identity to her female character only. Like a typical muse around 1900, Samir is used by Arnela as a projection surface: she interacts with him in a rather self-reflective way. However, in contrast to modernity, this contemporary female artist does not idealise her male muse: she is fully aware of and highlights the fact that Samir has no creative talents himself and that he does not entirely understand her world, from which he stays excluded. This has a negative impact on his task of being a source of inspiration for her: although Samir is supposed to be Arnela's muse, the narrator mentions (as a structural parallel to sexual pleasure) that it is he who is inspired by her experiences, and not the other way round. In some way, these changes destroy the union of the artist and the muse; the functional connection between them is split, or more precisely, Bašić's female artist is so heavily in control of the connection between herself and her muse that she destroys Samir as a possible source of inspiration, if we bear in mind that from the beginning the inspirational power of the muse was based on the artist's subjective attributing of this power to her. 
The fact that Bašić's narrator depicts a male muse without any special erotic appeal or artistic talent may be due to different reasons. On the one hand, the author thereby reinforces her female artist's demonstrative independence of men. On the other hand, this can be seen as a rhetoric strategy to anticipate the heroine's desertion of her partner. Bašić's most important subversive strategy, which contributes to her feminist intention, can, however, be seen in the fact that she allows her female character to have more unshared thoughts. Her narrator even gives Samir less room to think: throughout the story, it is Arnela who knows what she is going to do, without sharing any of her thoughts with him. Thereby, she makes it possible for Samir to overestimate his own part in this artistic relationship, although he can do nothing to save their future.

Arnela watches Samir the way a painter looks at his model, not the way a woman looks at a desired man. She studies physiognomic shapes and details of his body, not the individual character of a dear friend. By doing so, she behaves like a female dandy.

Nakon kupanja oboje se ugnijezde ispred televizora. Samir gleda neki dokumentarac o Drugom svjetskom ratu, a Arnela gleda njega. Pamti crte njegovog lica, oblinu čela, krivulju usana, teksturu kože. Proučava ga, kao da je on model koji treba što je vjernije naslikati. Udiše njegov miris i zna da ga nakon nekog vremena više neće moći dozvati u pamćenje. (Bašić 2017: 106)

(After a bath, both make themselves comfortable in front of the television. Samir is watching a documentary about the Second World War, and Arnela is watching him. She is trying to remember his facial features, the round of his forehead, the curves of his lips, the texture of his skin. She is studying him as if he were a model that one has to paint as faithfully as possible. She is inhaling his scent and knows that after some time she will not be able to recall it anymore.)

However, while the narrator is implicitly laughing about Samir, Arnela's secret decision to leave implies her own giving in to a situation she cannot change. In the background, or one might even say in the foreground, of this secret relationship between a female artist and her male muse is Samir's official relationship with his wife, who will soon give birth to their first child. Samir's fatherhood will give him a position as a creator, not erotically or artistically but biologically. Throughout the story, Arnela's dominant part in the relationship is emphasised, although it is actually broken at the very moment he becomes a father. Samir's upcoming 
parenthood is framed as his anticipated regress: he is about to further develop his caring identity in the context of his family. While the emphasis on this imminent 'degeneration' is the argumentatively prevalent reason for Arnela’s leaving, the 'other' reason, namely her jealousy, is never given, and yet made implicitly obvious by at least one random sentence: "Kada je prvi put čula da je Samirova žena trudna, Arnela je reagovala kao ranjena zvijer razjarena od bola.” (Bašić 2017: 102) (When Arnela came to know that Samir's wife was pregnant, she reacted like a beast that is hurt and furious with pain.) Samir's fatherhood will strengthen his family bonds and thereby threaten his loving attention for Arnela. She anticipates that it will be hurtful to receive proudly sent photos of the child, as they will imply the message that she is excluded from this new, most intimate part of his life.

While Bašić tells the story of a female artist possessing her male muse, she also tells the story of a female lover losing her caring partner to another woman. There is an overemphasis on the female dandy, which contributes to the idea that Bašić tells the story of the male muse to hide how much her female artist is hurt.

\section{Dijala Hasanbegović's Female Artist in the Poem "Moj prvi single" ("My First} Single”)

Adisa Bašić's story illustrates some potential areas of conflict in a relationship between an independent female artist and a domestic male muse: in the given case, the union is dysfunctional as the artist fails to control her muse, despite her highly emphasised sexual and artistic power. This is only one possible reason for Dijala Hasanbegović's lyrical subject to refuse any type of cooperation with men - professional as well as private. In the poem "Moj prvi single”, the author discusses the position of a female poet with a rather broad focus on art production and art reception. Her lyrical subject has no male muse, and, in contrast to Bašić, Hasanbegović does not try to represent caring masculinity as weak. She addresses gendered conflicts of power within a system of art production, which she outlines as structured by patriarchally transmitted claims of validity. She speaks with the voice of a female poet who looks down on the self-proclaimed masculine genius, which she denotes as loud, selfpublicising, and presumptuous. Like in Bašić's story, her lyrical subject writes back against a patriarchal system that she is effectively unable to change. 
A mi koji se ne manifestiramo

Čistimo vašu mast $\mathrm{s}$ naših laminata

Na koje se sliva vaša jetra

Vaša jetra gospodine pjesniče

Pamti vaše najbolje kreativne dane
And we, who are not demonstrating,

Clean your lard from our floors

On which outpours your liver

Your liver, Mister Poet,

Remembers your best creative days

Onako kako to mozak neće nikad. In a way the brain never will.)

(Hasanbegović 2017: 16)

Hasanbegović attacks the poet's, the editor's, and the professor's masculinity with her satirical comments in a way very different from Bašić's: she declares her competitor's creative abilities as void, his poems as trivial, his wording as corny, and his success as ephemeral. Furthermore, she highlights his self-promotion and frames (female) artistic quality as silent, decent, and modest.

The poem has many layers and illustrates different relations within a male-dominated literary scene: it challenges male colleagues, male editors, and male professors who discuss and promote the works of their male protégés. Hasanbegović outlines male characteristics as the only prerequisite for their claim to power and validity and refuses this way of legitimation. She explains mentorship (of exclusively male artists) as the (male) editor's subconscious effort to compensate for a narcissistic injury: the inferiority complex resulting from his own lack of artistic talent and career.

Gospodine sjedokosi uredniče

javi mi se kad uspiješ u životu!

Call me maybe!

Slobodno se javi i oboje ćemo biti

mali i nesretni

ti ćeš i dalje biti onaj

koji je htio na mome mjestu

neko kvalitetno neko kurčevito

neko slojevito muško

što se ne srami od svoga pisanja

cirkus da pravi da šuta da luta

da psuje da bude fanki da bude panki
(Dear grey-haired editor, contact me, if you have time for this in your life! / Call me maybe!

Feel free to contact me and both of us will be little and unhappy

you will continue to be the person who wanted in my place someone with quality, someone with a dick someone thoroughly male who is not ashamed of his writing, who behaves flamboyantly, who jokes, who is crazy, / someone who swears, who is 
da bude prostonarodni duhoviti heroj funky, who is punky, / who is an

Kakav sam nikad nisi bio.

(Hasanbegović 2017: 19-20) unsophisticated and witty hero / That you yourself never have been.)

What is conceptually interesting in Hasanbegović's statement is that she rudely formulates thoughts that usually remain unarticulated. In her readings, she stages the present poem effectively, sitting next to her real male editor or promoter and other, usually male, poets. Therefore, even though Hasanbegović in some way frames her female subject as subordinate and thematically reproduces a rather traditional narrative of suppression, she overcomes this narrative at the same time, as she herself in fact actively participates in the literary scene and directly faces her opponents. With her performance, she refuses to give in to the problems she evokes.

Refusal also stays the main theme in the concluding statement of this poem, where the lyrical subject prohibits the grey-haired editor from making any changes in her manuscript:

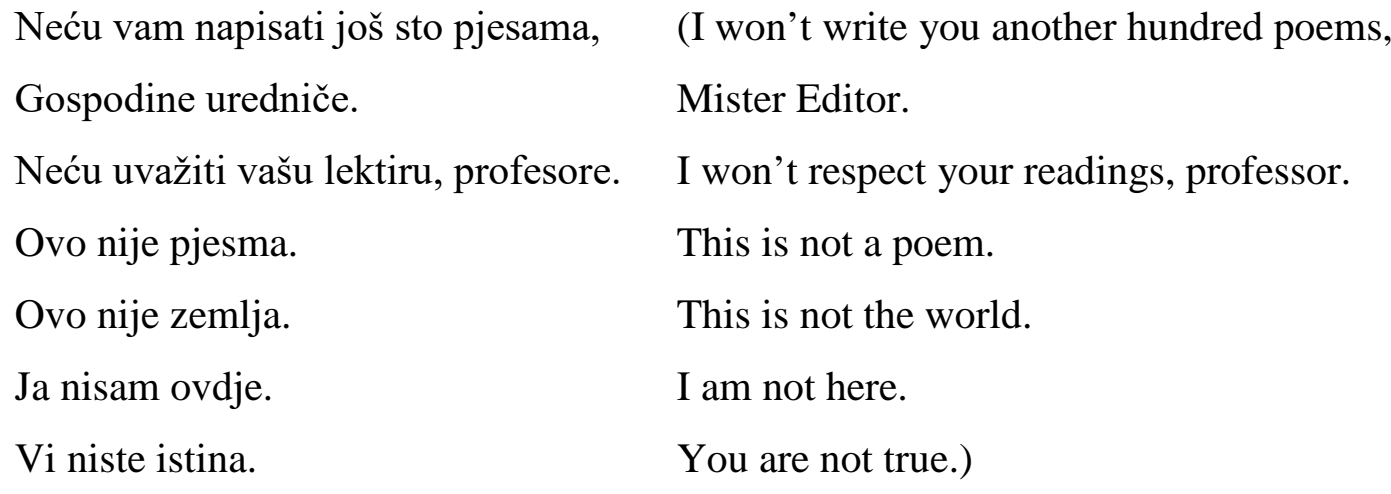

(Ibid. 20)

Slightly different from the connection to a muse, the cooperation between the author and the editor opens up a connection between inspiration and creation, too. In this case, however, the comments - as a possible source of inspiration - do not seem to advance the text as intended but threaten to extinguish the artist. Hasanbegović's conception does not include a typical muse, neither male nor female. Her speaker stages herself alone in front of a patriarchal system with a long-standing tradition. She neither tries to blend into this male-dominated setting by adopting the role of a muse, nor does she revolt against it by outlining her own exuberant sexual or artistic potential. From a certain distance, she satirically discusses the gendered perception and production of artists and insists on the fact that especially female artists are often not measured by their art but defined by a male-dominated literary industry. 
Hasanbegović's strategy to write about men, however, entails the fact that editors, poets, and grey-haired professors in some way become her muses: they become the subjects of her poetry, unable to define or protect themselves. It cannot be ruled out that their artistic representation in Hasanbegović's poem is shaped by the same distortions with which Picasso decided to depict Dora Maar.

\section{Inspiration and Self-Concept: Lana Bastašić's Novel Uhvati zeca (Catch the} Rabbit)

All three feminist texts that have been discussed so far depict the failure of the classic union of a female artist and a male muse. In each text, the contact with men initiates moral and artistic destruction, be it on the level of art (Drakulić), on one of partnership and affection (Bašić), or on a structural level (Hasanbegović). Lana Bastašić's novel Uhvati zeca, in contrast, shows an ideal imaginary union between the female protagonist Sara and her childhood love Armin. This union has never been realised because of the war in Yugoslavia, where Armin disappeared without a trace. Nonetheless, even 20 years later, he constitutes an important source of inspiration and vital energy for Sara, who is introduced as the author of the novel. Bastašić's book shows clear feminist features: for example, it contains manifold masculine lovers and interested candidates, who are, not without humour, all outlined as clumsy, sexually impotent, boring, aggressive, or slightly perverse. Still, these unflattering studies of men are never hostile or pained as in the texts analysed above. The narrator simply does not take these characters too seriously, a fact that is linked to Sara's persisting feelings for Armin, which outshine any other relationship.

Sara's literary creation is closely linked to Armin. She mentions that, regardless of his absence, he inspired her to write one of her first stories, where she used him as a prototype to shape the main character. However, beside the part he played as a literary motif, Armin is also the person who awakened Sara's consciousness, not only of literature but also of herself:

Pita me koja mi je omiljena boja, tek tako. Kažem zelena. Pita me koji mi je omiljeni oblik. Moram da razmislim. Osjetim tanjirić na svom krilu i kažem krug. "To je dobar oblik”, kaže mi on, a ja sam odjednom ponosna. [...] [N]isam do prije nekoliko sekundi ni znala da imam svoj oblik. On mi postavlja gomilu pitanja, više nego što mi je učiteljica postavila tokom cijele godine. Ali ne glupa pitanja, ne teška pitanja - ne, on 
me pita o meni. Koje mi je omiljeno godišnje doba, koja mi je omiljena životinja, koji mi je omiljeni broj. (Bastašić 2019: 79)

(He asks me what my favourite colour is, just like that. I say green. He asks me what my favourite shape is. I have to think about it. I feel the small plate on my lap and say "circle." "This is a good shape," he tells me, and I feel proud at once. [...] [U]p to a few seconds ago, I did not know that I had my own shape. He asks me lots of questions, more than my teacher has asked me during the whole year. But no stupid questions, no difficult questions - no, he asks me about me. What is my favourite season, what is my favourite animal, what is my favourite number.)

Since this first encounter at a children's birthday party, Sara has been searching for her own answers to those questions, which he was able to answer so naturally for himself. The importance of this conversation lies in the reflective process that Armin initiates. For the first time in her life, someone has asked Sara's subjective opinion, and he thereby awakens her wish to define herself. While in Drakulić's novel Picasso asks Dora to follow in his own footsteps and Hasanbegović's male editors transform the lyrical subject's text beyond recognition, Armin does not suggest anything to Sara but opens her mind to an indefinite world and the manifold ways one may look at it. Consequently, as the first-person narrator of Uhvati zeca, she positions herself as a highly subjective and transformative creator of the recounted past: “Osim toga, šta ti znaš o uspomenama? Bacaš ih za sobom kao iskorištene tampone. Ovo ću ja da ispričam, kao i sve. Škola, tmuran dan [...]. I tada te ugledam. Tada počinješ da postojiš. Prava ti, bez imena.” (Bastašić 2019: 161-162) (Moreover, what do you know about memories? You throw them away behind yourself like used tampons. I will tell this story, and everything. The school, a cloudy day [...]. And then I saw you. Then you began to exist. The true you, without a name.)

Sara randomly meets Armin only a few times before he irreversibly disappears. Each of these encounters cautiously hints at their mutual affection for each other. At one time, Armin, who is four and a half years older than her, undoes her ponytail: "“Vidiš, tako je bolje. Kao Venera.' ‘Kao šta?’, pitala sam ga.” (Bastašić 2019: 50) ('You see, it’s better like that, like a Venus.' 'Like what?', I asked him.) Especially retrospectively, when Sara begins to write, this fragile relationship stays an intellectually challenging and at the same time harmonious union of the artist and her muse, who in this way can be understood as her imaginary communication partner. The self-reflective character of this emotional bond leads back to the original concept 
of the muse as an absent source of inspiration that initiates and accompanies the creative act. Through different times of life, the memories of Armin confront Sara with unknown questions that she carefully tries to resolve and that will continue to be her secret source of vital and creative energy. Despite his absence, Sara maintains this relationship on several levels: until graduation, she and his sister Lejla refuse to overtly acknowledge Armin's death, while at the same time the great loss effects a wide range of emotions that includes mourning and gratitude for having made his acquaintance. If nothing else, this ambiguous state between Sara's remembering and redefining him will constitute one main chronotope of the novel Uhvati zeca: her fantasy of his return.

The mainly imaginary relationship between Sara and Armin illustrates some key prerequisites for an artistically productive realisation of the union between an artist and a muse. The latter cannot be a source of inspiration by defining the artist's work and path but by opening his or her eyes to important questions or topics and by making room in his or her mind for new insights and thoughts. Physical absence might facilitate such a union as the artist will fill the empty space with expectations, such as the anticipation of a possible reunion, and independently work out unsolved questions, which leads him or her to creation. Even more important, however, is the emotional quality of the relationship: in the previously discussed examples, the relationship of an artist and a muse is constructed along a hierarchical dichotomy, defined by categories of suppression and submission. For this reason, one of the partners - and usually the female creator - will finally be condemned to give in. Bastašić, in contrast, discards the idea of an affectionate connection as a basis for an abiding relationship of mutual love and unity that also empowers her main character to be creative.

\section{Conclusion: Fragile Artist, Fragile Muse}

In at least three of the discussed examples, the productive relationship between artistic women and inspiring men is doomed to fail. The respective feminist authors implicitly blame men for this, who are too possessive, too weak, too proud, or too biased by a male-dominated canon. Drakulić reacts to such an insight by emphatically sympathizing with her female protagonist, Bašić's female character proudly looks down on her partner, trying to hide how much she is hurt, and Hasanbegović's subject speaks out to the audience to declare her rejection of patriarchal principles throughout the literary industry.

Although Bastašić does not hide her feminist position when she exposes the moral or personal weakness of men, she clearly depicts Sara's connection with Armin as a loving and 
artistically inspiring union: the productive relationship of the artist and the muse resembles the ancient prototype of a muse who stays physically absent but provides the artist with the gift of speech.

One major difficulty that the female artists face in the other settings is linked to an actual relationship, which makes it more difficult to idealise their partner as a potential muse. Drakulić fictionally reconstructs Dora Maar's psychological and artistic destruction by Picasso, who not only refuses to be a muse to her but even restricts her artistic independence. What is more, Picasso's paintings seem to confirm his secret fear of Dora's own artistic performance as do his attempts to bring her down morally and to restrict her identity to that of a woman fully possessed by him. In line with the historical setting, the conception of Dora as a muse follows the topos of modernity that is linked to the femme fatale.

As Carola Hilmes (1990: XI) underlines, the femme fatale brings seduction and pain to men, but her most frequent fate is to be killed in the end. Picasso's Dora is not killed but emotionally broken, which also entails serious consequences for her health. Hilmes (1990: 65) links aggression against the femme fatale to a crisis of male self-confidence, which is provoked by her sensuality: the sexual obsession to possess her is accompanied by the man's fear of her power and by his envying her for the same. This may explain Picasso's jealous and nervous aggression against Dora, which is found in Drakulić's novel as well as in his own paintings.

Furthermore, at this point, a connection to the motif of the 'beautiful dead body', which Elisabeth Bronfen links to the concept of the modern muse, appears. She discusses historical and literary examples where the death of a muse increased her inspiring effect on the artist (cf. Bronfen 1994: 516-552). Picasso’s paintings of Dora’s living body rather show something different: they give proof of the fact that creation can be an aggressive act against the model. Drakulić imagines Dora's possible pain when she is confronted with Picasso's visual deformations of her own body. By exposing her suffering, he even distorts her soul. For the historical Picasso, this may have been one further reason to fear Dora as an artist with a camera: she appropriates his appearance and might even record his weak moments ${ }^{11}$ in a way that does not correspond to his self-image. As a subject of art, the muse has, thus, to be recognised as exposed and fragile.

Bašić and Hasanbegović define the female artist's identity reactively. Both try to reverse an imaginary patriarchal constellation of power: by depicting an uncreative, caring, and subordinate lover that is about to be abandoned, Bašić constructs and emphasises the fragility of Samir as a muse. Hasanbegović does this even more violently with male editors and colleagues when she frames the latter as self-publicising and overrated and the former as grey- 
haired, proud, and driven by their failed attempt to become artists themselves. Both strategies aim to free the female creator by rhetorically reducing her structural dependence on a loving partner and the literary scene. Although Bašić and Hasanbegović hit sensitive spots, their muses, who also resemble enemies or oppressors, seem resistant to their verbal aggression. Even though these texts can fulfil a cathartic function, they do not entirely hide the wounded female subject in their centre. Thus, one may see Bašić's and Hasanbegović's approaches in relation to the modern muse, as they relate to the problem of possessing, dominating, or influencing an autonomous subject who is claimed as the artist's model.

The main structural difference of Bastašić's male muse is Armin's sad absence. He is fragile not as a person but as a victim of war, and Sara's memory does not confront her with his but with her own fragility of searching for someone dear who will stay absent forever. Armin is not as absent as the muses of antiquity but far less close than those of modernity. He cannot be approached and does not have to be defeated: this imaginary relation is introspective, reflection-oriented, and inspiring in a constructive way. The female artist does not remember his death but his warm, intelligent, and mind-opening personality in life.

As is the case with any love relationship, that of an artist and a muse can also develop in a constructive or toxic way. This is already evident by the traditional topos of the male artist and his female muse and its shift from antiquity to modernity. The examples of the female artist and her male muse seem to demonstrate that gender identity is not of primary importance to constitute and frame a relationship between an artist and a muse. At the same time, they reflect historically shaped constructs and developments of relationships: the beginnings of modern women's emancipation in the twentieth century (not least in terms of their identity as artists) and the societal limits they faced, as well as feminist ideas and movements in the twenty-first century. The female artists no longer seem directly oppressed by a hegemonic masculine lover, but they still face a crisis for lack of an ideal union: because of a weak, indefinite partner or an outdated system.

The relationship of an artist and a muse always combines two realities: that within arts and the personal one. Writing about a muse can easily mean to miss the real person (Drakulić, Bašić, Hasanbegović), just as having missed someone (Bastašić) can be one reason to write about him or her. Imaginary shifts between a relationship and a piece of art may be productive. As all examples mention the hidden or overt emotional suffering of the artist or the muse, it seems, however, important - especially within the transgressive context that artistic production represents - to bear in mind the fragility of the artist and the muse. 


\footnotetext{
${ }^{1}$ A version of this paper was presented at the lecture series "Women in Balkan Literature and Culture: Subversive Readings and Identity Challenges" organized by the universities of Ghent and Manchester. I would like to thank the organisers Dr Miglena Dikova-Milanova and Dr Adelina Angusheva-Tihanov for their invitation.

${ }^{2}$ Aage Hansen-Löve (2019: 681-690) discusses similar questions for poets of the Russian Silver Age. ${ }^{3}$ All translations by I. J.

${ }^{4}$ In the visual arts, the erotic dimension of the relationship between an artist and a muse was a common motif already during the Renaissance (cf. Tutter 2019: 4).

${ }^{5}$ See The Return of Philip Latinovicz. Translated by Zora Depolo. Evanston, Illinois: Northwestern University Press, 1959.

${ }^{6}$ Translated into English by Christina Pribichevich Zorić.

${ }^{7}$ The translation into English by Christina P. Zoric.

${ }^{8}$ For the outlined reasons, I do not share the psychoanalytical interpretation of Guernica and the related materials as Picasso's re-enactment of his childhood trauma, his jealous reaction to the birth of his younger sister, elaborated in the two papers quoted. There the horse is seen as a symbol of his mother, which seems to me to be a misinterpretation of Freud: the symbolic relation between mother and horse is present in the individual case study of 'little Hans' in Analyse der Phobie eines fünfjährigen Knaben (1909, Analysis of a Phobia In a Five-Year-Old Boy), but Freud never claimed it to be a general archetype.

${ }^{9}$ Cf. also Peter Read's comment: "Portraits of Marie-Thérèse are often exquisite and often show her as serenely beautiful, but the most powerfully assertive female presence in the exhibition is that of Dora Maar." (cf. Read 2020:19)

${ }^{10}$ In some sources, the light bearer is identified as Dora Maar (cf. Caws 2000: 9).

${ }^{11}$ Cf. e.g. Dora Maar’s photograph of sleeping Picasso (cf. Baring 2017: 170).
} 


\section{References}

Attia, Ora. “Separation and individuation in Picasso’s Guernica”. The International Journal of Psychoanalysis No. 92: 6. (2011), 1561-1581.

Baring, Louise. Dora Maar. Paris in the time of Man Ray, Jean Cocteau, and Picasso. New York et al.: Rizzoli, 2017.

Bastašić, Lana. Uhvati zeca. Sarajevo, Zagreb: Buybook, 2019.

Bašić, Adisa. A ti zaključaj. Sarajevo: Buybook, 2017.

Bašić, Adisa. Komički pristup erotskoj ljubavi u odabranoj južnoslavenskoj lirici. Graz: Dissertation, 2019.

Bie, Oskar. "Musen”. In Ausführliches Lexikon der griechischen und römischen Mythologie. Bd 2/2, editor: Wilhelm Heinrich Roscher, Sp. 3238-3295. Leipzig: Teubner, 1894-1897.

Bronfen, Elisabeth. Nur über ihre Leiche. Tod, Weiblichkeit und Ästhetik. München: Deutscher Taschenbuch Verlag, 1994.

Burkhart, Dagmar. “'Göttlicher Hunger’. Slavenka Drakulićs Literarischer Kannibalismus als multiple Chiffre”. Südost-Forschungen No. 63-64 (2004): 339-359.

Caws, Mary Ann. Dora Maar with \& without Picasso. A Biography. London: Thames \& Hudson, 2000.

Drakulić, Slavenka. Dora i Minotaur. Moj život s Picassom. Zagreb: Fraktura, 2015.

Freud, Sigmund. Analyse der Phobie eines fünfjährigen Knaben. Frankfurt am Main: Fischer Taschenbuch, 1909. 
Gundulić, Ivan. Osman. Sarajevo: Svjetlost, 1990.

Hansen-Löve, Aage Ansgar. Schwangere Musen - Rebellische Helden. Antigenerisches Schreiben. Von Sterne zu Dostoevskij, von Flaubert zu Nabokov. Paderborn: Wilhelm Fink, 2019.

Hartke, Raul. “The primal scene and Picasso’s Guernica”. The International Journal of Psycho-Analysis No. 81, 1(2000): 121-139.

Hasanbegović, Dijala. Neće biti djece za rat. Zenica: Vrijeme, 2017.

Hilmes, Carola. Die Femme fatale. Ein Weiblichkeitstypus in der nachromantischen Literatur. Stuttgart: Metzler, 1990.

Homer. Odyssee. Stuttgart: Reclam, 1986.

Jandl, Ingeborg. “Ženski likovi kao orijentir u vanjskom svijetu i ogledalo duše. Nepoznata ljepotica u umjetničkom diskursu moderne: Antun Gustav Matoš, Ivo Andrić, Aleksandr Blok i Oscar Wilde”. In Šesti hrvatski slavistički kongres. Zbornik radova sa znanstvenoga skupa s međunarodnim sudjelovanjem održanoga u Vukovaru i Vinkovcima od 10. do 13. rujna 2014, editors: Stipe Botica, Davor Nikolić, Josipa Tomašić, Ivana Vidović Bolt, 493-503. Zagreb: Hrvatsko filološko društvo, 2016.

Krleža, Miroslav. Povratak Filipa Latinovicza. Zagreb: Minerva, 1932.

Krleža, Miroslav. The Return of Philip Latinovicz. Translated by Zora Depolo. Evanston, Illinois: Northwestern University Press, 1959.

Matoš, Antun Gustav. Utjeha kose. Poezija i proza. Zagreb: Mladost, 1991.

Read, Peter. "Shadows and shape-shifting. Pablo Picasso and Dora Maar, together and apart”. Times Literary Supplement. No. 6103 (2020): 18-19. 
Tutter, Adele. "Introduction: Mnemosyne, Mother of the Muse". In The Muse: Psychoanalytic explorations of creative inspiration, editor: Adele Tutter, 1-10. London, New York: Routledge, 2017. 


\section{Ингеборг Јандл}

ingeborg.jandl@univie.ac.at

Универзитет у Бечу

Факултет за филологију и студије

културе

Катедра за словенске студије https://doi.org/10.18485/knjiz.2021.11.11.5

УДК: 821.163.42.09-31 Дракулић С.

821.163.4(497.6).09-31 Башић А.

821.163.4(497.6).09-31 Хасанбеговић Д. 821.163.41(497.6).09-31 Басташић Л.

821:305-055.2

Оригинални научни чланак

\section{Уметница и њена муза: од женских тела ка женским идентитетима (Дракулић, Башић, Хасанбеговић, Басташић)}

Овај текст испитује грађење уметничког идентитета кроз призму текстова женских аутора 21. века. Узимајући у обзир античке и модерне конструкције односа између ствараоца и музе, чланак се у првој линији бави феминистичким стратегијама идеалног јединства, вековима обликованим унутар патријархалног контекста стваралаштва. Славенка Дракулић, Адиса Башић, Дијала Хасанбеговић и Лана Басташић користе се различитим субверзивним стратегијама како би испитале и измениле оквире задате тим контекстом. У овој анализи можемо поћи од тешкоћа са којима се еманципована модерна муза сусреће у настојању да буде препозната као самостална уметница. У одабраним књижевним текстовима видимо активније деловање које подразумева преокретање традиционалних родних улога у љубавним односима, или књижевни обрачун са мушким колегама-профитерима са литерарне сцене. Имајући у виду да идеал односа између музе и ствараоца, то јест, између инспирације и креације, не треба бити нарушен, још једно питање које се отвара јесте и то у којој мери је укидање или проширивање ове конструкције оправдано.

Кључне речи: женски идентитети, уметнички идентитет, концепти музе, субверзивно писање 